\title{
Providing Women Equality in Kyrgyzstan: Legal and Historical Analysis
}

\author{
Gulsara Kuldysheva1, Shailoobek Paraidinuulu'1, Aktilek Atantaev', Aigul Mirzaeva², \\ Dinara Shookumova², Bolotbek Zhusupov³, Feruza Tanatarova1, Zhypargul Abdullaeva ${ }^{* *}$ (D), \\ Nurkanbek Patiev ${ }^{1}$
}

\author{
${ }^{1}$ Department of the Theory and History of Government and Law, Osh State University, Osh, Kyrgyzstan \\ ${ }^{2}$ Department of the Civil Law and Procedure, Osh State University, Osh, Kyrgyzstan \\ ${ }^{3}$ Department of Criminal Law and Procedure, Osh State Law Institute, Osh, Kyrgyzstan \\ ${ }^{4}$ Science and Research Department, Osh State University, Osh, Kyrgyzstan \\ Email: *jypar.science@oshsu.kg
}

How to cite this paper: Kuldysheva, G., Paraidinuulu, S., Atantaev, A., Mirzaeva, A., Shookumova, D., Zhusupov, B., Tanatarova, F., Abdullaeva, Z., \& Patiev, N. (2021). Providing Women Equality in Kyrgyzstan: Legal and Historical Analysis. Open Journal of Social Sciences, 9, 328-333.

https://doi.org/10.4236/jss.2021.91024

Received: December 6, 2020

Accepted: January 23, 2021

Published: January 26, 2021

Copyright $\odot 2021$ by author(s) and Scientific Research Publishing Inc. This work is licensed under the Creative Commons Attribution International License (CC BY 4.0).

http://creativecommons.org/licenses/by/4.0/

\begin{abstract}
The article describing issues in consolidating women political and civil rights equality in Kyrgyzstan during the period of socialism. For almost seventy years of the Soviet Union period, all the constitutions in force in Kyrgyzstan invariably proclaimed the principle of men and women equality, and its implementation with concretization in relation to certain spheres, areas in the political, economic, cultural and social life was widely reflected by Soviet legislation. In providing the women equality in Soviet Kyrgyzstan, similarly as in other republics of the Soviet Union, the central place was occupied by solving the women emancipation problem, ensuring her legal and de facto equality.
\end{abstract}

\section{Keywords}

Human Rights, Women Rights, Equality, Emancipation, Inequality, Gender Equality

\section{Introduction}

The issues of women rights and freedom after the October Revolution in $1918^{\text {th }}$ radically changed social relations and brought freedom from exploitation and class inequality, which also influenced the position of women in society (Mullaney, 1984; Rendle, 2017). After the October Revolution of 1918, the laws of the Russian Empire that limited women rights were canceled in relation to family and children, property, and divorce. For the first time, women obtained the rights to freely choose their profession, place of residence, and education. A decree issued 
introducing equal pay for equal work for men and women. The equality of women in political and civil rights was enshrined in the first Soviet Constitution, adopted in July 1918. Article 64 in this Constitution especially emphasized the right to elect and be elected is using by "citizens of both sexes" (Polenina, 1985).

For almost seventy years that have passed since then, all the constitutions in force in our country invariably proclaimed the principle of equality between women and men, and its implementation with concretization are concerning certain spheres, areas in political, economic, cultural, and social life were widely reflected throughout Soviet legislation. That is why the experience of solving the women's question in the Soviet Union (Conze, 2001; Zirin, 1991), is social task of historical importance in the achieving real equality between women and men in developing countries; its propaganda serves as an important stimulus for the struggle for women's rights throughout the world (Richmond, 2016; Marino, 2014).

In this article women function, role in the society, and equality rights were discussed based on the statistical and historical analysis methods.

Research problem in this article focused on the solving problems of women, their emancipation, and ensuring women legal and de facto equalities. Research objectives were women rights, women functions in the society, emancipation and equality.

\section{The Women Function in Society}

The concept of solving the women questions under socialism (Černá, 2006) is based on the fact that woman performs three main social functions in society: a citizen, a worker, and a mother (Smith, 2006; Barnett, 2004). Performed by women, each of these functions separately and all together contributes to the development of society. At the same time, the concept of solving the women problems in the USSR established as determining factor in the equality of women in society and in the family was their participation in social production and in socially productive labor (Lenin, 1919). At different stages of the Soviet state development specific issues related to the participation of women in state and public life, with their labor activity, raising the general educational and professional level solved as state tasks such as the industrialization in the country, the collectivization of agriculture, elimination of unemployment and illiteracy, the restoration of the national economy after the Great Patriotic War of 1941-1945, etc. Putting forward the task of involving women in the social production, the Soviet state simultaneously implemented as a whole range of measures designed to raise the qualifications of female labor.

The scientific and technological revolution has a significant impact on the women's work nature. Mechanization and automation of production processes, an increase in the scientific organization of labor contributes to the expansion of the boundaries of the use of female labor. Accordingly, the proportion of women in mechanical engineering, electrical engineering, instrument making, and other technically advanced industries is increasing. 
The formation process and development of the legislation in Kyrgyzstan on women rights and freedom influenced by historical, national, and everyday life conditions, traditions, and customs of the Kyrgyz people rooted in the distant past. In ensuring the equality of women in Soviet Kyrgyzstan, as in other republics of the Soviet Union, the central place occupied by solving the problem of women emancipation ensuring their legal and de facto equality.

Kyrgyz women never put up with their disenfranchised position and strove to participate in social, political, and cultural life. Their struggle for their rights became especially active in the Soviet times, which was largely facilitated by the policy of the Soviet state, widely involving women into public life. The new laws of Soviet power played a huge role in the emancipation of women (Engel, 1992; Buckley, 1981). In many cities and villages, immediately after the victory of the Soviet authority, women organizations arose that waged a decisive struggle to protect women rights. Women were more and more involved in the work of meetings, congresses, women clubs, red yurts, and farmer's houses (Beyer \& Kojobekova, 2019). Kaip Umetalieva, Alymkan Mamytkulova, and others were at the forefront of women fighting for the removal of the burqa, chichvan, chapan, overcoming kalym, and polygamy. Many women died in the emancipatory struggle for their rights, for overcoming feudal and religious prejudices at the hands of fanatics who stubbornly resisted the emancipation of women. Among them was one of the most active social activists Urkuya Salieva and others. The women of the republic raised their protest voices against the terror of their enemies. In the resolution of one of the women meetings it was said: "Hundreds and thousands of women of the East rose to fight seclusion, century-old slavery ways" (Newspaper Soviet Kyrgyzstan, 1927). Special mention should be made of the fact that equality of women and men de jure was never considered in the Soviet state as the identity of their legal status. The Soviet concept of solving the women questions proceed from the premise that a simple equalization of women and men rights does not yet ensure genuine equality of women, who are performing the same functions in society as men, and carry out their specific function is the motherhood.

Protection of the human rights of women under international law, and the Convention on the Elimination of All Forms of Discrimination against Women built on previous conventions, in article 7, the women access to decision-making in political and public life was concerned (United Nations, 2014). Women civil rights can be seen from the gender equality and migration facts (Sagynbekova, 2017).

\section{Equality between Women and Men}

Gender equality cannot be simultaneously the cause of both convergence and divergence, although empirical evidence of a positive equality correlation between men and women, gender differences in personality are overwhelming (Connolly et al., 2020).

Innovative and multidisciplinary research obtained from sociology, economics, and social work data across US and Europe address issues that potential 


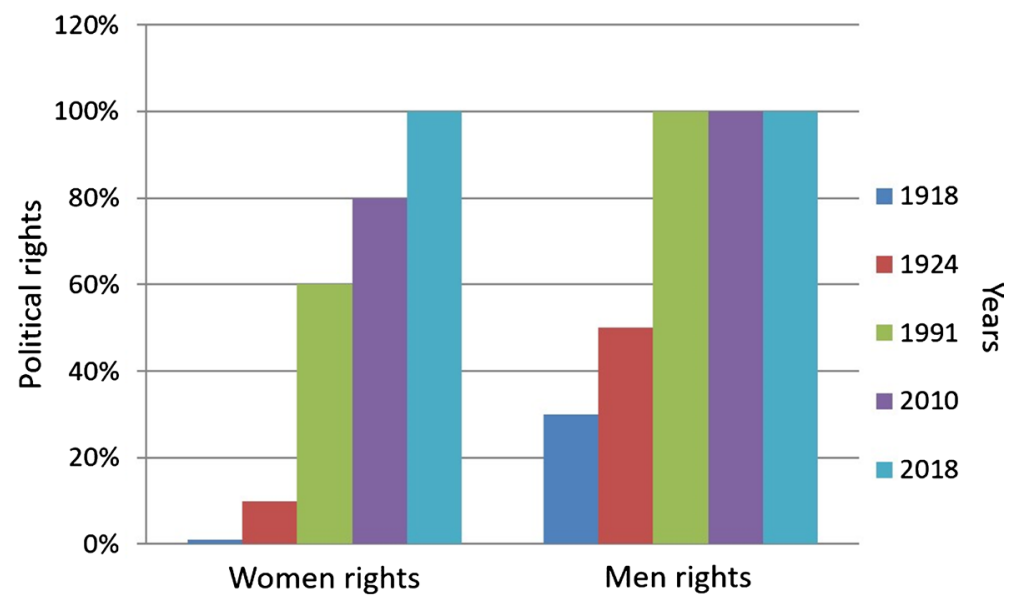

Figure 1. Women and men political rights increase from 1918 to 2018 years.

flexible working has influence on the gender division and work life balance (Chung \& van der Lippe, 2020).

It follows from true equality between women and men that it is possible only when women, having all the same rights as men, are also endowed with additional rights and privileges. That is why, according to article 35 of the USSR Constitution in 1977, not only equal opportunities in obtaining education and vocational training, in work, remuneration for it and promotion at work, in social, political and cultural activities, but also special measures to protect the labor and health of women: conditions allowing woman to combine work with motherhood; legal protection, material and moral supports for mothers and children, including the provision of paid leave and other benefits for pregnant women and mothers, a gradual reduction in the working hours of women with young children were established (Figure 1).

Women active participation in social production and political life often conflicts with the motherhood function perform by women and the traditional distribution of responsibilities in the family. That is why the family model under socialism, while summarizing the participation of all adult family members in the professional and socio-political life of society, at the same time presupposes the inevitable presence of feedback is society's help to the family (Kuldysheva, 2010).

\section{Conclusion}

Such assistance is comprehensive and includes measures related to improving the women conditions in family, the children rational combination in social and family education, reducing differences in family standards living depend on the presence of children, creating favorable conditions for the young families' life, etc. With the acquisition of independence at the constitutional level, having secured fundamental human rights and freedom, as well as the rights of the second and third generations, Kyrgyzstan was able to overcome the primacy of the state over the individual characteristics of the Soviet system, to establish the legal and 
institutional foundations for the acceptable protection and provision of human rights, including women rights. Research findings with analyses were made concerning women rights revealed their social functions, emancipation and equality in obtaining education and training, in work, political and cultural activities, labor protection and health.

\section{Conflicts of Interest}

The authors declare no conflicts of interest regarding the publication of this paper.

\section{References}

Barnett, R. C. (2004). Women and Multiple Roles: Myths and Reality. Harvard Review of Psychiatry, 12, 158-164. https://doi.org/10.1080/10673220490472418

Beyer, J., \& Kojobekova, A. (2019). Women of Protest, Men of Applause: Political Activism, Gender and Tradition in Kyrgyzstan. Central Asian Survey, 38, 329-345. https://doi.org/10.1080/02634937.2019.1631258

Buckley, M. (1981). Women in the Soviet Union. Feminist Review, 8, 79-106. https://doi.org/10.1057/fr.1981.13

Černá, M. (2006). Women under Socialism: What Degree of Emancipation? (p. 7). Cahiers du CEFRES $\mathrm{N}^{\circ} 30$, Le communisme à partir des sociétés-Communism from the Viewpoint of Societies. Cahiers du CEFRES, Centre Français de Recherche en Sciences Sociales (CEFRES). Communism from the Viewpoint of Societies.

Chung, H., \& van der Lippe, T. (2020). Flexible Working, Work-Life Balance, and Gender Equality: Introduction. Social Indicators Research, 151, 365-381.

https://doi.org/10.1007/s11205-018-2025-x

Connolly, F. F., Goossen, M., \& Hjerm, M. (2020). Does Gender Equality Cause Gender Differences in Values? Reassessing the Gender-Equality-Personality Paradox. Sex Roles, 83, 101-113. https://doi.org/10.1007/s11199-019-01097-x

Conze, S. (2001). Women's Work and Emancipation in the Soviet Union, 1941-50. In M. Ilič (Eds.), Women in the Stalin Era. Studies in Russian and East European History and Society (pp. 216-234). London: Palgrave Macmillan. https://doi.org/10.1057/9780230523425 12

Engel, B. (1992). Engendering Russia's History: Women in Post-Emancipation Russia and the Soviet Union. Slavic Review, 51, 309-321. https://doi.org/10.2307/2499534

Kuldysheva, G. K. (2010). State Administration and Local Self-Government (Legal Regulation) (248 p). Bishkek.

Lenin, V. I. (1919). Full Collection of Essays (Part 39, 201).

Marino, K. M. (2014). Marta Vergara, Popular-Front Pan-American Feminism and the Transnational Struggle for Working Women's Rights in the 1930s. Gender \& History, 26, 642-660. https://doi.org/10.1111/1468-0424.12093

Mullaney, M. (1984). Gender and the Socialist Revolutionary Role, 1871-1921: A General Theory of the Female Revolutionary Personality. Historical Reflections, 11, 99-151.

Newspaper Soviet Kyrgyzstan (1927). 10th February, Number 21.

Polenina, S. V. (1985). Soviet Woman in Society and Family. The Role of Women in Modern Society. Part II (pp. 203-218). Moscow.

Rendle, M. (2017). Introduction. Historical Research, 90, 3-10. 
https://doi.org/10.1111/1468-2281.12176

Richmond, S. J. (2016). History of Women's Rights in International and Comparative Perspective. In A. Wong, M. Wickramasinghe, R. Hoogland, \& N. A. Naples (Eds.), The Wiley Blackwell Encyclopedia of Gender and Sexuality Studies. https://doi.org/10.1002/9781118663219.wbegss355

Sagynbekova, L. (2017). International Labour Migration in the Context of the Eurasian Economic Union: Issues and Challenges of Kyrgyz Migrants in Russia. Working Paper No. 39. https://doi.org/10.2139/ssrn.3023259

Smith, T. A. (2006). The Emerging Female Citizen: Gender and Enlightenment in Spain. Berkeley, CA: University of California Press.

United Nations (2014). Women's Rights are Human Rights (123 p). HR/PUB/14/2, New York and Geneva.

Zirin, M. F. (1991). Women, Gender, and Family in the Soviet Union and Central/East Europe: A Preliminary Bibliography. In K. Offen, R. R. Pierson, \& J. Rendall (Eds.), Writing Women's History (pp. 457-516). London: Palgrave Macmillan.

https://doi.org/10.1007/978-1-349-21512-6_26 